\title{
Simulated Traffic Dynamic Loading on Physical Properties of a Red Latosol under No-Tillage
}

\author{
Divina Cleia Resende dos Santos ${ }^{1}$, Paulo Márcio Fernandes Viana ${ }^{1}$, Gisele Carneiro Silva ${ }^{2}$ \\ \& Elton Fialho dos Reis ${ }^{1}$ \\ ${ }^{1}$ Universidade Estadual de Goiás, Campus CCET, Anápolis, Goiás, Brazil \\ ${ }^{2}$ Universidade Estadual de Goiás, Campus Posse, Posse, Goiás, Brazil \\ Correspondence: Paulo Márcio Fernandes Viana, Universidade Estadual de Goiás, Campus CET, BR 153, \\ Fazenda Barreiro do Meio, Brazil. Tel: 55-623-328-1139. E-mail: Paulo@itec.eng.br
}

Received: November 21, $2017 \quad$ Accepted: January 15, $2018 \quad$ Online Published: March 15, 2018

doi:10.5539/jas.v10n4p192 URL: https://doi.org/10.5539/jas.v10n4p192

The research is financed by Coordination for the Improvement of Higher Education Personnel (CAPES).

\begin{abstract}
The use of intensive mechanization in no-tillage areas can change soil physical conditions, mainly in the "Cerrado", which has reduced cover ratio. This study aimed to evaluate physical and mechanical properties of a red latosol under no-tillage and subjected to simulated dynamic traffic in different surfaces conditions. For this, soil samples were collected, with dimensions of $0.2 \times 0.2 \times 0.3 \mathrm{~m}$ (height, width and length), in an area subjected to no-tillage in the last four years. Subsequently, samples were transported to the laboratory and subjected to different traffic levels in a simulator. Shortly after, a completely randomized experimental design was set up, in factorial $2 \times 5$, with two covers (with and without haystack) and five traffic levels (zero, one, two, four and eight run overs) applied by the simulator. Assessed physical properties were superficial settlement, soil density, compaction degree and pre-consolidation pressure. Results showed that superficial settlement, soil density and compaction degree were significantly influenced by soil cover and traffic intensity. Pre-consolidation was not affected by cover, and had higher values when subjected to more traffic intensity.
\end{abstract}

Keywords: soil physical techniques, soil mechanics, soil physical properties, pre-consolidation pressure

\section{Introduction}

The cultivation and some soil management practices promote changes in soil physical properties, primarily in the structure, which can promote short-term cultures growth. However, intensive exploitation and demanding, intense and lasting work schedules can degrade soils by changing their physical properties, such as density, compressibility, hydraulic conductivity and water infiltration rate (Pruski, 2009), especially in no-tillage system.

The no-tillage system is based on the absence of soil disturbance, in its permanent cover and crop rotation. Soil no tillage favors the accumulation of organic material for its lower decomposition rate (Kalbitz \& Kaiser, 2008). The soil cover with crop residues can reduce the density of the surface layer, thus minimizing problems caused by compression (Silva et al., 2010). When assessing the effects of additional compaction caused by machine traffic under no-tillage system, Streck et al. (2004) concluded that the penetration resistance values increased according to traffic intensity.

Agricultural machinery traffic is appointed as a determining factor in the occurrence of soil compaction (Veiga et al., 2007). The application of dynamic loads by axles and agricultural implements in the soil produces tensions in the soil/tire and soil/implement interfaces, in surface and depth, respectively. These tensions compact the different soil layers (Horn \& Lebert, 1994) and, if this dynamic load exceeds the soil internal resistance, physical properties changes in the deeper layers will occur (Bola et al., 2007). By studying five different traffic intensities, in field and laboratory, taking into account that a properly adapted traffic simulator was used in the laboratory to the condition of agricultural soil, Couto et al. (2013) observed that traffic intensity influenced soil physical properties, and that the highest soil superficial settlement occurred right after the first tire run over, and from the eighth run over, settlement increased in relation to the traffic of one run over, although being similar to two and 
four run overs treatments. In addition, technical feasibility of using the traffic simulator to reproduce or predict changes in the state of soil compaction was proved.

Soil compaction is one of the most important physical properties, as it modifies the number and distribution of pore sizes. This occurs when a given external pressure is applied to the soil, which may be caused by traffic of agricultural machinery, transportation equipment or animals (Lima et al., 2004). The amount and flow of water in the soil can be changed by compaction, which modifies water availability to plants, what may have adverse effects. In a soil with good fertility, when compacted, plants cannot extract nutrients present in it, due to mechanical restrictions to root growth (Gubiani et al., 2014; Ortigara et al., 2014). Compaction decreases soil porosity, and subsequently the amount of oxygen available in the rhizosphere, which can be limiting in plant metabolism (Capuro et al., 2014).

Soil compressibility is related to its structure and the state of acting tensions (Imhoff et al., 2004). The maximum tension that the soil has been already subjected is known as pre-consolidation pressure (or historic tension), which reflects the history of soil tensions, indicating, theoretically, the highest pressure that the soil has already supported in the past, in addition to being also an estimation of soil load bearing capacity (Dias junior et al., 2007). Uniaxial compression tests have been used to evaluate soil compaction. This test allows to obtain the soil compression curve, which graphically represents the relation between the applied pressure logarithm and soil density, void ratio, thus allowing to determine the compressibility coefficient $(\mathrm{Cc})$, and the pre-consolidation pressure ( $\sigma p)$ of soil (Rosa et al., 2011).

The objective of this study was to evaluate the physical and mechanical properties of an Oxisol under no-tillage when subjected to simulated traffic in conditions of cover and without cover surfaces.

\section{Material and Methods}

Sample collection area is located in the municipality of Goianápolis-GO, Brazil, whose geographical location is defined by the coordinates $16^{\circ} 27^{\prime} 52.51^{\prime \prime} \mathrm{S}$ and $49^{\circ} 0^{\prime} 46.27^{\prime \prime} \mathrm{W}$, with an average altitude of $980 \mathrm{~m}$ and $1 \%$ declivity. The soil in the area is a red latosol (EMBRAPA, 2006) and was under no-tillage over a period of four years. The total area used in the experiment was of approximately $400 \mathrm{~m}^{2}$, with dimensions of $20 \times 20 \mathrm{~m}$, homogeneous. The field condition during the test referring to the physical and mechanical properties of the soil are given in Table 1.

A completely randomized design was adopted in a factorial design, with two cover types, five compaction energies and four replicates per treatment, totaling 40 experimental units using the same soil type. For this, two covers were used, with and without haystack (A1 and A2), and five traffic levels or compaction energies: zero (E0), one (E1), two (E2), four (E3), and eight (E4) run overs of the traffic simulator wheel.

The withdrawal procedure of undisturbed samples was based on the NBR 9604 (ABNT, 1986). Samples had dimensions of $0.2 \times 0.2 \times 0.3 \mathrm{~m}$ (height, width and length).

Table 1. Physical and mechanical characterization values of a dark red latosol under no-tillage in a depth from 0 to $0.10 \mathrm{~m}$

\begin{tabular}{|c|c|c|c|c|c|c|c|c|c|c|c|c|}
\hline \multicolumn{10}{|c|}{ Physical Properties } & \multirow{2}{*}{\multicolumn{3}{|c|}{ Mechanic Properties }} \\
\hline \multicolumn{3}{|c|}{ Textural Analysis } & \multicolumn{4}{|c|}{ Physical Indexes } & \multicolumn{3}{|c|}{ Consistency Limits } & & & \\
\hline $\begin{array}{l}\text { Sand } \\
\left(\mathrm{g} \mathrm{kg}^{1}\right)\end{array}$ & $\begin{array}{l}\text { Silt } \\
\left(\mathrm{g} \mathrm{kg}^{-1}\right)\end{array}$ & $\begin{array}{l}\text { Clay } \\
\left(\mathrm{g} \mathrm{kg}^{-1}\right)\end{array}$ & $\begin{array}{l}\mathrm{W}^{(1)} \\
(\%)\end{array}$ & $\begin{array}{l}\delta^{(2)} \\
\left(\mathrm{t} \mathrm{m}^{-3}\right)\end{array}$ & $\begin{array}{l}\rho^{(3)} \\
\left(\mathrm{t} \mathrm{m}^{-3}\right)\end{array}$ & $\begin{array}{l}\eta^{(4)} \\
(\%)\end{array}$ & $\begin{array}{l}\text { LL } \\
(\%)\end{array}$ & $\begin{array}{l}\text { LP } \\
(\%)\end{array}$ & $\begin{array}{l}\mathrm{LC} \\
(\%)\end{array}$ & $\begin{array}{l}\rho_{\text {dmáx }} \\
\left(\mathrm{t} \mathrm{m}^{-3}\right)\end{array}$ & $\begin{array}{l}\mathrm{W}_{\text {ot }} \\
(\%)\end{array}$ & $\begin{array}{l}\mathrm{GC} \\
(\%)\end{array}$ \\
\hline 520 & 130 & 340 & 18.5 & 2.47 & 1.08 & 56.2 & 33.82 & 25.09 & 18.9 & 1.53 & 24.7 & 69.3 \\
\hline
\end{tabular}

Haystack used in the experiment was taken in the field. The area was previously cultivated with soybean, so the used haystack consisted of soybean residues (Glycine max L.) and pasture. In the blocks, the proportional value of $5 \mathrm{tha}^{-1}$ was used.

To evaluate the effect of different traffic levels on the physical and mechanical properties of the soil in the laboratory, a linear traffic simulator was used, which was properly adapted to the condition of agricultural soil according to Couto et al. (2013). The wheel simulator was composed of a rotary cultivator tire with the following 
characteristics: Diagonal construction, measure of 4.80-8 and two plies, PowerTrack model manufactured by Carslisle.

To simulate the pressure applied to the soil, a New Holland TT $403055.1 \mathrm{~kW}$ (75 hp) agricultural tractor was used as reference, with diagonal construction rear tire and the following technical specifications: $16.9 \times 30 \mathrm{R} 1$, Dyna Torque II model, with pressure of $137.9 \mathrm{kPa}$ for the tests. Contact area was determined according to the methodology proposed by Couto et al. (2013).

For the purpose of loading samples surfaces, a hydraulic jack with the capacity of two tons of force was used. The load applied by the jack was monitored by a $200 \mathrm{kgf}$ load cell positioned between samples support plate and the jack.

The following variables were analyzed: surface settlement, soil density, degree compaction and pre-consolidation pressure.

Superficial settlement was measured using the photographic method described in detail by Couto et al. (2013). Soil density was determined by volumetric ring method by (Embrapa, 1997). Compaction degree was obtained by dividing soil density by the maximum soil density, which was obtained in the Proctor test. Pre-consolidation pressure was determined through the simulator traffic in each experimental plot, using an automatic consolidometer. Undisturbed samples were collected and assayed on endometrial glands, where static charges of $12.5,25,50,100,200,400$, and $800 \mathrm{kpa}$ were applied. Pre-consolidation pressure ( $\sigma \mathrm{p})$ was calculated by Pacheco Silva method, described in the NBR 12007/90 (ABNT, 1990).

Obtained variables were submitted to analysis of variance by $\mathrm{F}$ test at $5 \%$ probability, and when there was a significant difference between treatments their means were compared by Tukey test. In all statistical procedures the SISVAR 5.3 program was used.

\section{Results and Discussion}

Analysis of variance results showed that all variables were influenced by the cover type and simulator wheel traffic, but only, since the interaction between covers and the different traffic levels have not influenced the variables significantly (Table 2).

Tabela 2. Summary of the analysis of variance of the variables: surface settlement, soil density, compaction degree and after pre-consolidation pressure

\begin{tabular}{|c|c|c|c|c|c|}
\hline \multirow[b]{2}{*}{ Treatments } & \multirow[b]{2}{*}{$\mathrm{DF}^{(1)}$} & \multicolumn{4}{|c|}{ Average Square } \\
\hline & & $\begin{array}{l}\text { Surface } \\
\text { settlement }\end{array}$ & Soil density & $\begin{array}{l}\text { Compaction } \\
\text { degree }\end{array}$ & $\begin{array}{l}\text { Pre-consolidation } \\
\text { pressure }\end{array}$ \\
\hline Cover types (C) & 1 & $0.4074^{*}$ & $0.012250^{*}$ & $62.335958^{*}$ & $652.6875^{*}$ \\
\hline Traffic levels (T) & $4(3)$ & $2.5342 *$ & $0.008572 *$ & $30.982718^{*}$ & $154046.68^{*}$ \\
\hline $\mathrm{C} \times \mathrm{T}$ & $4(3)$ & 0.0454 & 0.001150 & 5.823423 & 89.7875 \\
\hline Residue & $30(24)$ & 0.0438 & 0.000943 & 3.470057 & 736.0208 \\
\hline C.V. & - & 12.2 & 2.7 & 9.5 & 10.6 \\
\hline Media & - & 1.7073 & 67.7380 & 1.2153 & 255.4375 \\
\hline
\end{tabular}

Note. DF: Degrees of Freedom; ${ }^{(1)}$ DF values in parentheses refer to soil repression because there is no witness. * Significant at $5 \%$ probability by the test of F. CV: Coefficient of variation (\%).

In traffics performed with and without the presence of cover on the soil surface, a significant difference was obtained between the two conditions for soil settlement. Similar data were found by Braida et al. (2006), who worked the effect of soil organic matter in the behavior of the compression curve, where they observed that the haystack, during the Proctor test, dispelled up to $30 \%$ of the used compaction energy, confirming the hypothesis that the existing haystack on the ground is able to absorb some of the compaction energy produced by machine and animals traffic.

In the bare soil, tension applied by eight run over traffic increased settlement in relation to the traffic of one run over, since treatments of two and four run over had similar results. Cover soil differed significantly on two and one traffic run over, but had not differed for four and eight run over (Table 3). Botta et al. (2009) reached similar conclusions when induced tractor traffic on the no-tillage system and in a soil with history of conventional planting in five different traffics. According to these authors, tension values in the soil and the vertical 
displacement measured for the first run over were significantly affected by dynamic loads, and it was also observed that the soil on the conventional system, which have not had a cover, had a higher settlement than the soil with no-tillage.

After the passage of the traffic simulator wheel, the average density of the soil without cover showed a value of $1.12 \mathrm{~g} \mathrm{~cm}^{-3}$, while cover soil value was of $1.08 \mathrm{~cm}^{-3}$, showing that haystack influenced significantly in the reduction of the load applied by the axle, with reduction in soil density values. Therefore, soils with cover levels above $5 \mathrm{t} \mathrm{ha}^{-1}$ have reduced compaction levels in surface layers. Other authors, such as Streck et al. (2004) and Rosim et al. (2012) had already reported the haystack in reducing soil compaction.

The average values of soil density shown in Table 2 evince that there were differences between the mean numbers of traffic simulator wheel run overs between the different levels of loads applied to the soil. With one run over there was no significant increase compared to control (zero run over). The highest increase in the average soil density occurred after the second run over. With four and eight run over it was observed that it had not differed statistically from two run overs. There was an increase in soil density with increase in the number of run overs of the simulator wheel, and similar results were found by Mentges et al. (2010). The intensity of traffic has negative effects on the physical and hydraulic properties of the soil, increasing density values and penetration resistance.

Table 3. Mean values of soil settlement $(\mathrm{mm})$, soil density $\left(\mathrm{g} \mathrm{cm}^{-3}\right)$, compaction degree and pre-consolidation $(\mathrm{kPa})$ after application of the traffic levels

\begin{tabular}{lllll}
\hline Run overs & Settlement & Density & Compaction degree & Pre-consolidation \\
\hline 0 & - & $1.06 \mathrm{~b}$ & $68.95 \mathrm{~b}$ & $83.25 \mathrm{c}$ \\
1 & $0.95 \mathrm{c}$ & $1.09 \mathrm{ab}$ & $71.65 \mathrm{ab}$ & $159.62 \mathrm{~b}$ \\
2 & $1.35 \mathrm{a}$ & $1.13 \mathrm{a}$ & $73.91 \mathrm{a}$ & $200.62 \mathrm{a}$ \\
4 & $1.20 \mathrm{~b}$ & $1.13 \mathrm{a}$ & $73.78 \mathrm{a}$ & $213.25 \mathrm{a}$ \\
8 & $1.4 \mathrm{a}$ & $1.10 \mathrm{a}$ & $73.13 \mathrm{a}$ & $215.33 \mathrm{a}$ \\
\hline
\end{tabular}

Results corroborate with those found by Silva et al. (2011), who assessing traffic intensity of two, four and eight times of a Forwarder on the compaction of a Haplustox, in the depths of ( 0 to $0.03 \mathrm{~m})$ and $(0.10$ to $0.13 \mathrm{~m})$, concluded that all traffic intensities caused soil compaction at both studied depths, and four run overs were the ones that caused higher soil compaction. A study perfomed by Couto et al. (2013) also showed similar results.

Despite the increase in soil density after simulated wheel traffic, soil density still had values that were considered ideal. This result is due to the fact that the water content in the soil (Table 1), was close to the shrinkage limit. According to Silva et al. (2003), when the soil is with moisture near the shrinkage limit, the soil can be trafficked, as smaller damage is caused to the soil structure. Similar results were found by Rosa et al. (2012) when evaluating the effect of traffic intensity and management system in the physical properties of an Ultisol, observing that there were no significant differences for the variable soil density, due to the high state of compaction and the low water content in the soil.

The mean values of soil compaction degree show that there were differences between the means in soils with cover and without cover. The values found for compaction degree in soils without cover were of 73.42 , which were higher values than those associated with cover, which were 71.14 , what was expected, because it was the one that had the highest soil density after the passage of the traffic simulator tire, so consequently the compaction degree without cover would also be higher. Soil density may suffer high texture influence, which can generate a comparison difficulty between soils with contrasting textures (Betioli Junior et al., 2012; Couto et al., 2013). What have not occurred because the used area was of small size and with very homogeneous soil.

The average values of soil compaction degree shown in Table 2 evince that there were significant differences between the different load levels. With one run over there was no significant increase compared to the control (zero run over). The largest increase occurred after the second run over, differentiating from control. The results corroborate with those reported by Oliveira et al. (2013) and Botta et al. (2009), who analyzing the soil surface compaction degree of had higher increments after the first run overs. Silva et al. (1997) showed the water physical behavior of a Red-Yellow Podzolic under different management systems. They also noted that soil density was strongly influenced by soil management, enhancing the effect of management type and machine traffic intensity on the soil. 
The water content in soil (Table 1) was close to the consistence limits of soil, making simulated traffic effects to be minimized. Marchão et al. (2007), through the study of the interrelations between physical properties and the water retention curve coefficients of a Dystrophic Red Latosol under different use systems, observed that soil physical attributes have higher degradation with increasing water content in the soil.

There was no significant effect of pre-consolidation pressure $(\sigma p)$ in relation to soil cover (with and without haystack) and in the interaction between soil cover and traffic level. These results differ from Krummelbein et al. (2008), who observed a significant difference in $\sigma p$ of areas with grass cover and without cover, and in areas without cover, $\sigma p$ decreased significantly. However, Mazurana et al. (2013), when evaluating the physical properties of an Alfisol under consolidated no-tillage with machinery traffic control, observed that the soil cover have not affect the physical properties. Only machines traffic interfered with physical properties, which showed lower macroporosity, indicating that this system have lower ability to withstand disturbances, what was also proved by the pre-consolidation pressure values.

The tension applied to the soil by traffic increased soil pre-consolidation pressure, thus increasing load bearing capacity. Therefore, it was less susceptible to additional compaction. The traffic of one run over differed from the control and from other run overs, but the one with two run overs was indistinguishable comparing to four and eight run overs treatments (Table 2). By studying the traffic intensity in the soil, Silva et al. (2003) observed that wheeled traffic intensity also changed compressibility, soil density, porosity and hydraulic conductivity of the saturated soil of a Dystrophic Red Latosol.

This result is in agreement with other studies (Silva et al., 2007; Dias Junior et al., 2008), which reported high deterioration of the soil structure with increasing number of machine run overs. According to Lima et al. (2012), soil compressibility and shearing parameters are influenced by compaction states.

\section{Conclusion}

The findings of this study in the entire measured traits indicated that soil settlement, soil density and compaction degree were significantly influenced by soil cover and traffic intensity. Pre-consolidation was higher when subjected to traffic compared to control. From two run overs there was no influence with increeasing traffic levels. Covered soil had lower density and compaction degree values. The highest increase in the soil average density occurred after the second run over.

\section{References}

Betioli Júnior, E., Moreira, W. H., Tormena, C. A., Ferreira, C. J. B., Silva, A. P., \& Giarola, N. F. B. (2012). Intervalo hídrico ótimo e grau de compactação de um Latossolo vermelho após 30 anos sob plantio direito. Revista Brasileira de Ciência do Solo, 36, 917-982. https://doi.org/10.1590/S0100-06832012000300027

Botta, G. F., Tolon, B. F. A. T., \& Bellora, T. (2009). Effect of the number of tractor passes on soil rut depth and compaction in two tillage regimes. Soil and Tillage Research, 103(2), 381-386. https://oi.org/10.1016/ j.still.2008.12.002

Braida, J. A., Reichert, J. M., Veiga, M., \& Reinert, D. J. (2006). Resíduos vegetais na superfície e carbono orgânico do sol o e suas relações com a densidade máxima obtida no ensaio Proctor. Revista Brasileira Ciência do Solo, 30(4), 605-614. https://doi.org/10.1590/S0100-06832006000400001

Capurro, E. P. G., Secco, D., Reichert, J. M., \& Dalvan, J. R. (2014). Compressibility and elasticity of a Vertissol affected by the intensity of grazing cattle. Ciência Rural, 44(2), 283-288. https://doi.org/10.1590/S010384782014000200014

Couto, R. F., Reis, E. F., Viana, P. M. F., Holtz, V., Oliveira, L. A., \& Alves, S. M. F. (2013). Compactação e recalque superficial de um Latossolo Vermelho em condição de campo e laboratório. Revista Brasileira de Engenharia Agrícola e Ambiental, 17(11), 1239-1245. https://doi.org/10.1590/S1415-43662013001100016

Dias Junior, M. S., Fonseca, S., Araújo Junior, C. F., \& Silva, A. R. (2007). Soil compaction due to forest harvest operations. Pesquisa Agropecuária Brasileira, 42(2), 257-264. https://doi.org/10.1590/S0100-204X20070 00200015

Dias Junior, M. S., Silva, S. R., Santos, N. S., \& Araujo Junior, C. F. (2008). Assessment of the soil compaction of two ultisols caused by logging operations. Revista Brasileira de Ciência do Solo, 32(6), 2245-2253. https://doi.org/10.1590/S0100-06832008000600004

Embrapa-Centro Nacional de Pesquisa de Solos. (1997). Manual de métodos de análise de solo (p. 212). Rio de Janeiro: Embrapa Solos. 
Gubiani, P. I., Reichert, J. M., \& Reinert, D. J. (2014). Interação entre disponibilidade de água e compactação do solo no crescimento e na produção de feijoeiro. Revista Brasileira de Ciência do Solo, 38(3), 765-773. https://doi.org/10.1590/S0100-06832014000300008

Horn, R., \& Lebert, M. (1994). Soil compactability and compressibility. In B. D. Soane, \& C. Van Ouwerkerk (Eds.), Soil compaction in crop production (pp. 45-69). Amsterdam: Elsevier. https://doi.org/10.1016/ B978-0-444-88286-8.50011-8

Imhoff, S., Silva, A. P., \& Fallow, D. (2004). Susceptibility to compaction, load support capacity, and soil compressibility of Hapludox. Soil Science Society of America Journal, 68(1), 17-24. https://doi.org/ 10.2136/sssaj2004.1700

Kalbitz, K., \& Kaiser, K. (2008). Contribution of dissolved organic matter to carbon storage in forest mineral soils. Plant Nutrition Soil Science, 171(1), 52-60. doi: 10.1002/jpln.200700043

Krummelbein, J., Peth, S., \& Horn, R. (2008). Determination of pre-compression stress of a variously grazed steppe soil under static and cyclic loading. Soil and Tillage Research, 99(2), 139-148. https://doi.org/ 10.1016/j.still.2008.01.008

Lima, C. L. R., Miola, E. C. C., Timm, L. C., Pauletto, E. A., \& Silva, A. P. (2012). Soil compressibility and least limiting water range of a constructed soil under cover crops after coal mining in Southern Brazil. Soil and Tillage Research, 124(177), 190-195. https://doi.org/10.1016/j.still.2012.06.006

Lima, C. L. R., Silva, A. P., Imhoff, S., Lima, H. V., \& Leão, T. P. (2004). Heterogeneidade da compactação de um Latossolo Vermelho-Amarelo sob pomar de laranja. Revista Brasileira de Ciência do Solo, 28(3), 409-414. https://doi.org/10.1590/S0100-06832004000300001

Marchão, R. L., Balbino, L. C., Silva, E. M., Santos Junior, J. D. G., Sá, M. A. C., Vilela, L., \& Becquer, T. (2007). Qualidade física de um Latossolo Vermelho sob sistemas de integração lavoura-pecuária no Cerrado. Pesquisa Agropecuária Brasileira, 4(6), 873-882. https://doi.org/10.1590/S0100-204X2007000600015

Mazurana, M., Fink, J. R., Silveira, V. H., Levien, R., Zulpo, L., \& Brezoln, D. (2013). Propriedades físicas do solo e crescimento de raízes de milho em um Argissolo Vermelho sob tráfego controlado de máquinas. Revista Brasileira Ciência do Solo, 37(5), 1185-1195. https://doi.org/10.1590/S0100-06832013000500008

Mentges, M. I., Reichert, J. M., Rosa, D. P., Vieira, D. A., Rosa, V. T., \& Reinert, D. J. (2010). Propriedades físico-hídricas do solo e demanda energética de haste escarificadora em Argissolo compactado. Pesquisa Agropecuária Brasileira, 45(3), 315-321. https://doi.org/10.1590/S0100-204X2010000300012

Oliveira, P. R., Centurion, J. F., Cruz, M. A. P., Franco, J., Souza Pereira, F., \& Júnior, L. S. B. (2013). Qualidade estrutural de um Latossolo Vermelho submetido à compactação. Revista Brasileira de Ciência do Solo, 37(3), 604-612. https://doi.org/10.1590/S0100-06832013000300006

Ortigara, C., Koppe, E., Luz, F. B. D., Bertollo, A. M., Kaiser, D. R., \& Silva, V. R. D. (2014). Soil use and physical-mechanical properties of a Red Oxisol. Revista Brasileira de Ciência do Solo, 38(2), 619-626. https://doi.org/10.1590/S0100-06832014000200026

Pruski, F. F. (2009). Conservação de solo e água: Práticas mecânicas para o controle da erosão hídrica (2nd ed., Cap. 8, pp. 216-259). Viçosa: UFV.

Rosa, D. P., Reichert, J. M., Mentges, M. I., Rosa, V. T., Vieira, D. A., \& Reinert, D. J. (2011). Métodos de obtenção da capacidade de suporte de carga de um Argissolo cultivado. Revista Brasileira de Ciência do Solo, 35(5), 1561-1568. https://doi.org/10.1590/S0100-06832011000500010

Rosa, D. P., Reichert, J. M., Mentges, M. I., Rosa, V. T., Vieira, D. A., \& Reinert, D. J. (2012). Demanda de tração e propriedades físicas de um Argissolo em diferentes manejos e intensidades de tráfego. Pesquisa Agropecuária Brasileira, 47(1), 118-126. https://doi.org/10.1590/S0100-204X2012000100016

Rosim, D. C., Maria, I. C., Silva, R. L., \& Silva, Á. P. D. (2012). Soil compaction in a rhodic hapludox soil as influenced by straw management and quantity on surface. Bragantia, 71(4), 502-508. https://doi.org/ 10.1590/S0006-87052013005000003

Silva, A. G., Crusciol, C. A. C., Soratto, R. P., Costa, C. H. M., \& Neto, J. F. (2010). Produção de fitomassa e acúmulo de nutrientes por plantas de cobertura e cultivo da mamona em sucessão no sistema plantio direto. Ciência Rural, 40(10), 2092-2098. https://doi.org/10.1590/S0103-84782010001000007 
Silva, A. P., Kay, B. D., \& Perfect, E. (1997). Management versus inherent soil properties effects on bulk density and relative compaction. Soil and Tillage Research, 44(1-2), 81-93. https://doi.org/10.1016/S0167-1987 (97)00044-5

Silva, R. A., Dias Júnior, M. S., \& Leite, F. P. (2007). Camada de resíduos florestais e pressão de preconsolidação de dois Latossolos. Pesquisa Agropecuária Brasileira, 42(1), 89-93. https://doi.org/ 10.1590/S0100-204X2007000100012

Silva, R. A., Dias Junior, M. S., \& Leite, F. P. (2011). Avaliação da intensidade de tráfego e carga de um forwarder sobre a compactação de um Latossolo Vermelho-Amarelo. Revista Árvore, 35(3), 547-554. https://doi.org/10.1590/S0100-67622011000300017

Silva, R. B., Dias Junior, M. S., Silva, F. A. M., \& Fole, S. M. (2003). O tráfego de máquinas agrícolas e as propriedades físicas, hídricas e mecânicas de um Latossolo dos cerrados. Revista Brasileira de Ciência do Solo, 27(6), 973-983. https://doi.org/10.1590/S0100-06832003000600002

Streck, C. A., Reinert, D. J., Reichert, J. M., \& Kaiser, D. R. (2004). Modificações em propriedades físicas com a compactação do solo causada pelo trafego induzido de um trator em plantio direto. Ciência Rural, 34(3), 755-760. https://doi.org/10.1590/S0103-84782004000300016

Veiga, M., Horn, R., Reinert, D. J., \& Reichert, J. M. (2007). Soil compressibility and penetrability of an Oxisol from southern Brazil, as affected by long-term tillage systems. Soil and Tillage Research, 92(1-2), 104-113. https://doi.org/10.1016/j.still.2006.01.008

\section{Abbreviations}

Cc: compressibility coefficient; $\sigma \mathrm{p}$ : pre-consolidation pressure of soil.

\section{Copyrights}

Copyright for this article is retained by the author(s), with first publication rights granted to the journal.

This is an open-access article distributed under the terms and conditions of the Creative Commons Attribution license (http://creativecommons.org/licenses/by/4.0/). 